\title{
Piero Gobetti and his Writings on International Politics in The 1920s
}

\section{Francesca Somenzari}

\begin{abstract}
Università degli Studi di Torino Piero Gobetti (Turin 1901- Paris 1926) was not only one of the most important thinker and political writer of the Twentieth Century, but also one of the greatest organizers of culture: in his short life, he founded three journals (Energie Nove, Rivoluzione Liberale and II Baretti) and a publishing house (Piero Gobetti Editore). Within his prodigious intellectual activity (obviously against Mussolini and what he represented), there was also room for reflection on the international politics of the 1920s. Gobetti's attention to international politics was expressed first in Energie Nove and then in Rivoluzione Liberale, with projects of columns and unique numbers especially dedicated to some foreign countries ${ }^{1}$.
\end{abstract}

Keywords: Piero Gobetti, international politics

\section{Introduction}

The main focus of many of Gobetti's writings was the Versailles Conference together with the decisions it gave rise to: international issues were analyzed in the light of a perspective that explicitly rejects nationalism². As Gobetti stated: "Versailles not only is not a peace, but it excludes peace"3.

The writer's considerations and conclusions were strongly influenced by the thought of Gaetano Salvemini and- albeit to a lesser extent- seemed to refer to the Wilsonian teaching (despite the criticisms addressed to it at first).

\section{Gobetti and Russia: among history, ecstatic contemplation and Liberalism}

In Energie Nove (1918-1920) and Rivoluzione Liberale (1922-1925), Piero Gobetti wrote several essays on Russia and in particular on the 1917 Revolution; Language, Literature and Leninism were the three Ls sparking Gobetti's interest. Together with his wife, Ada, he began studying Russian with the aim of translating Andreiev's works ${ }^{4}$; but ultimately, it is the phenomenon of the Bolshevik revolution that motivated Gobetti's general passion for Russia.

In "Frammenti di estetismo politico" and "La Russia dei Soviet", Gobetti presented the Revolution as one of those mythical and unrepeatable events that history offers only rarely: for this reason it had to be contemplated rather than judged. As he reported:

The Russian Revolution is history, you must study it; it is a social phenomenon [...]. You have before you a world of constant progress, and you looked for the scheme in which to enclose it [...]. The Revolutions do not look at the past. They create and shape new realities. The government of Lenin

\footnotetext{
${ }^{1}$ Two issues of Rivoluzione Liberale were devoted to Germany and Great Britain, respectively in January and March-April 1924. Regarding France, see N. Bobbio, F.S. Nitti et al., Piero Gobetti e la Francia. Atti del colloquio italo-francese, Franco Angeli, Milano, 1985.

2 See F. Somenzari (edited by), Piero Gobetti. Vita internazionale, Aras, Fano, 2017, pp. 17-22.

3 P. Gobetti, II trionfo della democrazia, in "Rivoluzione Liberale" (from now on RL), II, n. 4, February 1st, 1923; the article is also included in P. Spriano (edited by), Scritti Politici, Einaudi, Torino, 1997, pp. 448-452.

Original text: "Versailles non solo non è una pace, ma esclude la pace".

${ }^{4}$ Gobetti defined Leonid Andreiev "the greatest of contemporary Russian writers". See P. Gobetti, Leonida Andreiev, in "Energie Nove" (from now on EN), II, n. 8, September 30, 1919.

Andreiev was defender of the revolution of 1905 and contrary to that of 1917, but above all he was against the excesses of Bolshevism.
} 
and Trotzki is a de facto government. It is the will of Russia. A state organization and not a scientific investigation. Life and not the book1.

Gobetti stressed the importance of such a simple and fundamental concept: the Revolution is a fact and a new democracy is born. At first, he seemed to categorically reject any form of manipulation of the phenomenon, preferring a historical and objective interpretation to one of political expediency.

In Gobetti's writings, Lenin and Trozki were called great statesmen who elevated Russia to the level of Western civilizations, facing dangerous government responsabilities ${ }^{2}$. And then:

They [Lenin e Trotzki ] are not only Bolsheviks; they are the men of action who have awakened a people and are recreating a soul for them ${ }^{3}$.

The position taken by Gobetti led the communist Antonio Gramsci to write that Gobetti was a young men who had understood the greatness of the Revolution and its leaders"4.

However, after this first contemplation of the phenomenon of the Russian Revolution, in 1921 Gobetti denied himself, by stating:

Trotzki affirms a liberal ${ }^{5}$ view of history [...]. Only for tactical necessities and for historical needs, the Revolution- full of Liberalism, in a country like Russia, home of the mir, worshiper of every form of community- must take the name and sometimes the appearance of socialist work [...]. It is up to the historian to affirm the truth above political contingencies ${ }^{6}$.

From the ascertainment of the extraordinary nature of the Revolution and from a gaze that wanted to be as objective as possible, Gobetti moved on to an extremely partial political interpretation, placing the Russian events into the riverbed of the liberalism current. According to Gobetti, Trotzki carried on (without knowing it) a liberal, non-socialist design.

In this case, Gobetti's interpretation is neither shareable nor sustainable, but it is very interesting because it clearly demonstrates the non-systematic nature of his thinking ${ }^{7}$.

\section{Gobetti and the United States of America}

In Gobetti's writings even the United States were taken into consideration and not by chance: the First World War brought about the entry of the United States themselves into European life and dynamics, especially at the end of the conflict. Although in the 1920s President Harding carried on the motto America first - the basis of a highly isolationist policy - the Wilsonian conception of Europe and international relations was destined to have a lasting echo in the Old Continent, even

\footnotetext{
${ }_{1}$ P. Gobetti, Frammenti di estetismo politico, in EN, II, n. 10, November 30, 1919; the article is also included in P. Spriano (edited by), Scritti Politici cit., pp. 206-213. Original text: "La Rivoluzione Russa è storia, voi dovete studiarla; è un fenomeno sociale [...]. Avete dinanzi un mondo in formazione, e voi cercato lo schema in cui rinchiuderlo [...]. Le Rivoluzioni (e tutta la storia del resto) non guardano il passato. Creano e plasmano nuove realtà. II governo di Lenin e Trotzki è un governo di fatto. E' la volontà della Russia. Un'organizzazione statale e non un'indagine scientifica. La vita e non il libro".

2 See P. Gobetti, La Russia dei Soviet, in "Volontà", February 15, 1921; the article is also included in P. Spriano (edited by), Scritti politici cit., pp. 197- 206, p. 197.

3 P. Gobetti, Rassegna di questioni politiche, in EN, II, n. 6, July 25, 1919, pp. 132-139; the article is also included in P. Spriano (edited by), Scritti politici cit., p. 151. Original text: "Non sono solo dei bolscevichi, sono gli uomini d'azione che hanno destato un popolo e gli vanno ricreando un'anima".

${ }^{4}$ P. Gobetti, Paradosso sullo spirito russo, Einaudi, Torino, 1969, p. XXI.

5 In this case, the adjective "Liberal" has to be understood in its historical sense, that is "relative to the Liberal Party". Today the term "Liberal" is used with the meaning of "progressive".

${ }^{6}$ P. Gobetti, Trotzki, in "Il resto del Carlino», April 5, 1921; the article is also included in P. Spriano (edited by), Scritti Politici cit., pp. 206210. Original text: "Trotzki afferma una visione liberale della storia [...] Soltanto per necessità tattiche e per esigenze storiche quest'opera [la rivoluzione] feconda di liberalismo, in un paese come la Russia, patria del mir, adoratrice di ogni forma di comunità, deve prendere il nome e talvolta anche le apparenze di opera socialista [...]. Spetta allo storico affermare la verità al di sopra delle contingenze politiche". ${ }^{7}$ See P. Polito, L'eresia di Piero Gobetti, Raineri Vivaldelli, Torino, 2018.
} 
by virtue of territorial changes which it produced at the Versailles Conference. The Fourteen Points and the birth of the League of Nations deeply engraved on the new European balance ${ }^{1}$.

In the above-mentioned journal "Energie Nove", Gobetti focused on Wilsonism and the League of Nations; the writer's judgment on this international organization (wanted by the Democratic President) was in some ways cautious and even a little suspicious: according to Gobetti, the League of Nations was characterized by excessive abstractness and a utopian vision that damaged its own work. So wrote Gobetti:

To correctly understand and evaluate everything that passes under the name of the League of Nations, we cannot stop at an examination of the potential abstract value of the idea, but we must immediately see its value in relation to social life, that is we must study in which practical forms it [the League] can be implemented ${ }^{2}$.

It was not only the idea itself relevant, but its practical implementation, its sustainability: "the politician feeds on reality".

The appeal to democracy as a pivot of peaceful coexistence and a guiding principle of international relations alone was not enough, beyond the morality that this internationalist project carried with it. On this point, Gobetti was very close to Salvemini's position.

Beyond the criticisms, in the pages of Gobetti there is however the recognition of the value of the New Diplomacy, that is of a vision that, in spite of its specific and contingent limits, will reveal itself in the long-term forward-looking.

A few years later, on the occasion of Wilson's death, Gobetti wrote:

To realize his greatness, the judgment must instead concern his American figure, in the history of America. His own election to the presidential seat is a solemn fact: as early as 1914 he had turmed out to be a great statesman. After the mediocrity of presidents like Taft or Roosevelt, the temper of a Lincoln emerges in Wilson ${ }^{3}$.

\section{References}

[1] E. Alessandrone Perona, Le provocazioni della ricerca, in "Passato e Presente", n. 97, 2016, pp. 103-120

[2] L. Beghin, Da Gobetti a Ginzburg. Diffusione e ricezione della cultura russa nella Torino del primo dopoguerra, Istituto storico belga di Roma, Roma-Bruxelles, 2007

[3] N. Bobbio, F.S. Nitti et al., Piero Gobetti e la Francia. Atti del colloquio italo-francese, Franco Angeli, Milano, 1985

[4] B. Bongiovanni, Da Marx alla catastrofe dei comunismi. Traiettorie e antinomie del socialismo, Unicopli, Milano, 2000

A. Cabella (edited by), Gobetti tra Riforma e rivoluzione, Franco Angeli, Milano, 1999

[5] M. Cattaruzza, L'Italia e la questione adriatica (1918-1926). Dibattiti parlamentari e panorama internazionale, II Mulino, Bologna, 2014

[6] J. B. Duroselle, Da Wilson a Roosevelt. La politica estera degli Stati Uniti dal 1913 al 1945, Cappelli, Bologna, 1963

\footnotetext{
1 It's essential to remember that, based on the principle of self-determination of peoples, the Austro-Hungarian Empire had disintegrated, giving rise to numerous national states; moreover, with respect to Italy, Wilson had taken a very tough position, denying it some strategic territories. See M. Cattaruzza, L'Italia e la questione adriatica (1918-1926). Dibattiti parlamentari e panorama internazionale, II Mulino, Bologna, 2014.

${ }^{2}$ P. Gobetti, La Società delle Nazioni, in EN, I, n. 5, January 1-15, 1919; the article is also included in P. Spriano (edited by), Scritti Politici cit., pp. 65-67.

Original text: "Per intendere e valutare rettamente tutto ciò che passa sotto il nome di Società delle Nazioni, non ci possiamo fermare ad un esame del valore potenziale in astratto dell'idea, ma dobbiamo scendere subito a vederne il valore in relazione alla vita sociale, dobbiamo studiare cioè in quali forme pratiche essa si può attuare".

${ }^{3}$ P. Gobetti, Uomini e idee. Lo stile di Wilson, in RL, III, n. 7, February 12, 1924; the article is also included in P. Spriano (edited by), Scritti politici cit., pp. 591-593. Original text: "Per rendersi conto della sua grandezza il giudizio deve invece riguardare la sua figura di americano, nella storia dell'America. Già la sua elezione al seggio presidenziale è un fatto solenne: già nel 1914 si era rivelato un grande statista. Dopo la mediocrità di presidenti come Taft o Roosevelt, in Wilson si sente la tempra di un Lincoln".
} 
[7] L. Ginzburg, Gobetti e il significato della Rivoluzione Russa, in «Quaderni di giustizia e libertà», n. 5, dicembre 1932, pp. 88-92

[8] F.S. Nitti, La tragedia dell'Europa. Che farà l'America, Piero Gobetti Editore, Torino 1924

[9] F. S. Nitti, La Pace, Piero Gobetti Editore, Torino, 1925

[10] C. Panizza (edited by), L'autobiografia della nazione, Aras, Fano, 2016

[11] P. Polito, L'eresia di Piero Gobetti, Raineri Vivaldelli, Torino, 2018

[12] P. Polito, II liberalismo di Piero Gobetti, Centro Studi Piero Gobetti, Torino, 2006

[13] P. Polito, La rivoluzione russa come una rivoluzione liberale, in «Critica liberale», n. 225, vol. XXII, 2015, pp. 180-182

[14] G. Salvemini, Dal Patto di Londra alla Pace di Roma. Documenti della politica che non fu fatta, Torino, 1925

[15] G. Scroccu (edited by), Piero Gobetti. La "rigenerazione" dell'Italia e la politica del primo dopoguerra: gli anni di Energie Nove, Biblion, Milano, 2014

[16] F. Somenzari (edited by), Piero Gobetti. Vita internazionale, Aras, Fano, 2017

[17] F. Somenzari, Wilson, l'internazionalismo e la nuova diplomazia: un quadro complesso tra fallimento momentaneo e valore duraturo, in «Scienze e Ricerche», n. 24, marzo 2016, pp. 16-20

[18] P. Spriano (edited by), Scritti Politici, Einaudi, Torino, 1997 